\title{
WestVirginiaUniversity
}

THE RESEARCH REPOSITORY @ WVU

West Virginia Agricultural and Forestry Experiment

Davis College of Agriculture, Natural Resources

Station Bulletins

And Design

$1-1-1903$

\section{Experiments with buckwheat and oats}

\author{
J. H. Stewart
}

Horace Atwood

Follow this and additional works at: https://researchrepository.wvu.edu/ wv_agricultural_and_forestry_experiment_station_bulletins

\section{Digital Commons Citation}

Stewart, J. H. and Atwood, Horace, "Experiments with buckwheat and oats" (1903). West Virginia Agricultural and Forestry Experiment Station Bulletins. 84.

https://researchrepository.wvu.edu/wv_agricultural_and_forestry_experiment_station_bulletins/84 @ WVU. It has been accepted for inclusion in West Virginia Agricultural and Forestry Experiment Station Bulletins by an authorized administrator of The Research Repository @ WVU. For more information, please contact ian.harmon@mail.wvu.edu. 

Digitized by the Internet Archive in 2010 with funding from Lyrasis Members and Sloan Foundation 


\section{WEST VIRGINIA UNIVERSITY \\ AGRICULTURAL EXPERIMENT STATION, MORGANTOWN, W. VA.}

\section{EXPERIMENTS WITH}

\section{Buckwheat and Oats.}

By J. H. STEWART and HORACE ATWOOD.

[The Bulletins and Reports of this Station will be mailed free to any citizen of West Virginia upon written application. Address, Director of Agricultural Experiment Station. Morgantown, W. Va.] 


\section{THE REGENTS OF THE WEST VIRGINIA UNIVERSITY.}

NAME OF REGENT.

P. O. ADDRESS

Hon. W. J. W. Cowden, ................... Wheelin

HoN. C. M. BABB,

Falls

Hon. J. B. Finley,

Parkersburo

Hon. D. C. Gallaher,

. Charleston

Hon. E. M. Grant,

Morgantown

Hon. J. M. Hale.

Princeton

Hon. C. E. Hawortit, . . . . . . . . . . . . Huntington

Hon. C. R. OLdhai,.. .Moundsville

HoN. .J. R. 'T'ROTter.

Buckhannon

President of the Board of Regents,........W. J. W. Cowden President of the University, D. B. PuRinton Treasurer, A. R. Whitehils Auditor, W. J. WHITE

\section{STATION STAFF.}

JAMES H. StewaRT, A. MI.,........ Director and Agriculturist Bert H. Hite, M. S.,.......... Vice Director and Chemist S. W. Fletcher, Рн. D., .............. Horticulturist W. E. Rumser, B. S. Agr.,.......... Entomologist in Charge Horace Atwood, M. S. Agr.,.........AssistantAgriculturist Chas. D. Howard, B. S.,............... Associate Chemist F. B. Kunst, ..................... Assistant Chemist

E. S. Stalnaker, A. B.,................Assistant Chemist W. M. Morgan, B. S. A.,.......... Assistant Horticulturist Gilbert M. John, ...............Assistant Horticulturist W. J. Wніте, . . . . . . . . . . . . . . . Bookkeeper

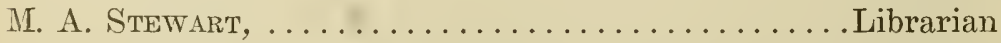
May IVATson, Stenographer 


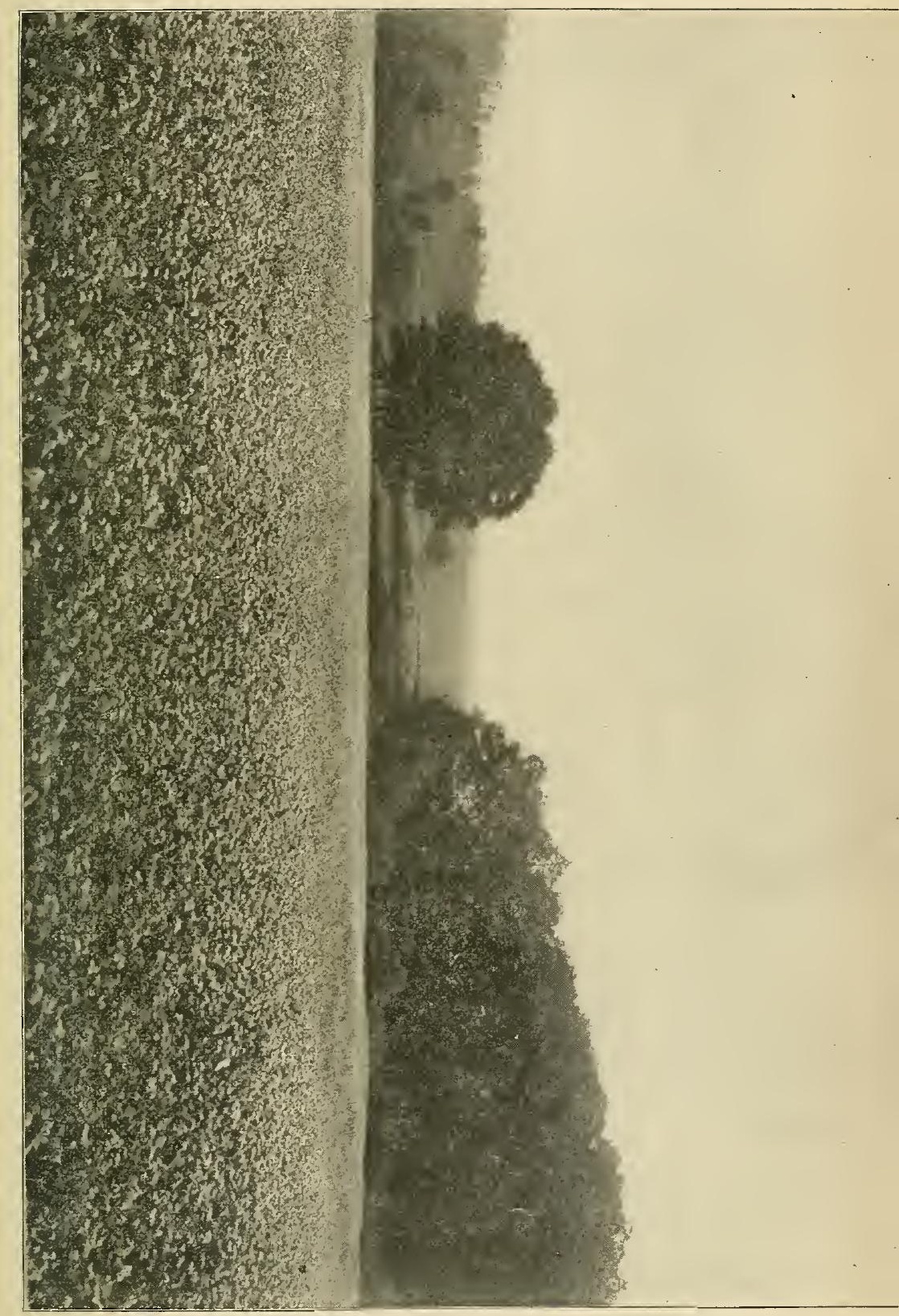





\section{Experiments with Buckwheat.}

According to the statisties of the United States Department of Agriculture there are only five states in the Union-Maine, New York, Pennsylvania, Michigan and Wiseonsin-which produce more buckwheat than West Virginia, while from twenty in twenty-five states produce more corn, wheat, rye, hay and potatoes. This fact indicates that there must be many sections of this State in which the climate and soil are naturally well adapt. ed to the production of buckwheat, and as the demand for buckwheat flour is increasing both at home and abroad, more attention should be paid to the culture of this crop, especially in the elevated portions of the State where the summers are not too hot. Buckwheat is easily. injured by hot, dry weather.

During the past five years the station has studied the influence of different fertilizers upon the yield of grain, and compared a few of the standard varieties. The experiments have been conducted at the station farm at Morgantown, and at the testing grounds in the glade district near Reedsville, in Preston county. The following tables give the main details of the fertilizer experiments.

The experiments conducted in Preston county have beer under the direct supervision of Mr. John Guseman, to whom acknowledgement is due for the care exereised in laying out the plats, applying the fertilizers, sowing the seed and harvesting the crops.

The following tables show the yield of buckwheat upon the experiment plats in Preston county, from 1898 to 1902 inclusive. The Japanese variety was used each year: 
RESULTS FOR 1898.

Sowed Jume 24th, harvested Sept. 7th.

IPPLICATION PER ACRE.

YIELD PER ACRE.

:00 1bs. sodium nitrate................. 17.5 bushels

400 ths. potassium sulphate.............21.2 bushels

400 tbs. acid phosphate................. 43.7 busheis

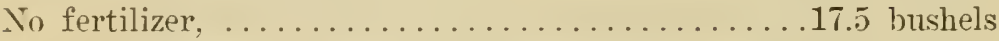

In 1898 the application of sodium nitrate was apparently of no benefit. The potassium sulphate increased the yield but slightly, while the acid phosphate more than doubled the yield compared with the plat to which no fertilizer was applied.

RESULTS FOR 1899.

Sowed July 10th, harvested Sept. 15th.

APPLICATION PER ACRE.

YIELD PER ACRE.

188 tbs. sodium nitrate.................. 10.0 bushels

90 lbs. potassium sulphate................ 17.7 bushels

77 Ibs. acid phosphate....................... bushels

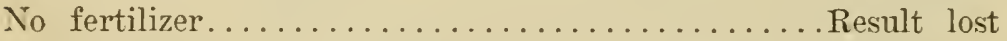

The acid phosphate plat yielded nearly twice as much as the potassium sulphate plat, and more than three times as much as the sodium nitrate plat. 

RESULTS FOR 1900.

Sowed June 25th, harvested Sept. 3rd.

APPLICATION PER ACRE.

YIELD PER ACRE.

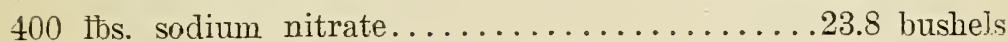

400 1bs. potassium sulphate.................... bushels

400 1bs. acid phosphate.................. 40.0 bushels

200 ibs. sodium nitrate.... 200 ibs. potassium sulphate. $\} \ldots \ldots \ldots \ldots \ldots \ldots . . \ldots \ldots$ bushels

200 ths. sodium nitrate.

200 ths. arid phosphate....

200 ibs. potassium sulphate.

200 ibs acid phosphate...

133 lbs. sodium nitrate.

133, ibs. potassium sulphate.

133 tbs. acid phosphate.

No fertilizer

.28 .3 bushels

.28 .1 busheìs

25.4 bushels

Neither the sodium nitrate nor the potassium sulphate materially increased the yield of grain, when used alone or in combination with each other. The acid phosphate, however, exerted a beneficial influence upon the yields of all the plats to which it was applied, the largest yield being obtained from the plat on which only acid phosphate was used.

\section{RESULTS FOR 1901.}

Sowed July 3rd, harvested Sept. 10th.

APPLICATION PER ACRE.

TIELD PER ACRE.

150 tbs. acid phosphate...................... 33.7 bushels

200 tbs. acid phosphate......................... bushels

300 tbs. acid phosphate..................... busheis

400 tbs. acid phosphate........................ bushels

200 lbs. acid phosphate, .....

200 tbs. sodium nitrate.... $\} \ldots \ldots \ldots \ldots \ldots .78$ bushels

200 lbs. acid phosphate,.....

200 lbs. Potassium Sulphate,

200 liss. acid phosphate.

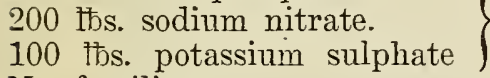

.39 .4 bushels

No fertilizer

40.2 busheis

No fertilizer but lime in 1899

22.7 bushels

32.1 busheis 
Regarding the application of different amounts of acid phosphate the table shows that amounts in excess of 150 ths. per acre increased the rield but slightly. The most striking result of this test was the beneficial effect of the lime which was applierl in 1899 at the rate of 30 bushels of stone lime per acre.

\section{RESULTS FOR 1902.}

Sowed July 8th, harrested Sept. 18th.

.IPPIICATION PER ACRE.

YIELD PER ACRE.

90 tbs. sodium nitrate...................23.4 bushels 200 1bs. acid phosphate....................... bushels 70 ths. potassium sulphate.............26.6 bushels No fertilizer ......................24.7 bushels 90 ibs. sodium nitrate. 200 1bs. acid phosphate.... 46.8 bushels $90 \mathrm{tbs}$. sodium nitrate.

70 ths. potassium sulphate.. 200 its. acid phosphate.

$\because 0$ ths. potassium sulphate. 90 Hts. sodium nitrate. 200 ths. acid phosphate. 70 tbs. potassium sulphate..

.34 .6 busheis

During this test wet weather somewhat injured the buckwheat ripon the first two plats, as a portion of each of these plats vas upon land slightly lower than the remainder of the field. The table, however, gives the actual yields.

In this experiment neither sodium nitrate nor potassium sulphate was of much benefit when used alone, but when used in connection with each other a better result was obtained. The acid phosphate, as in former years, increased the yield of all of the plats to which it was applied.

\section{General Summary.}

The tests for five years show that a fertilizer for buckwheat raised on the glade lands of Preston county should be very rich in phosphoric acid, and possibly should contain a small amount of nitrogen and potash. 


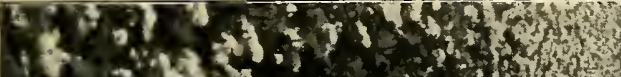
$774,0,154$

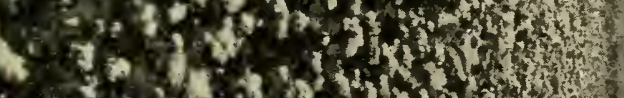

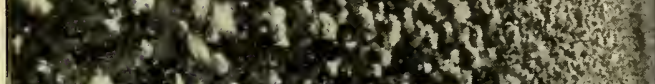

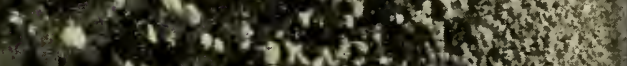

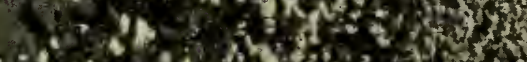

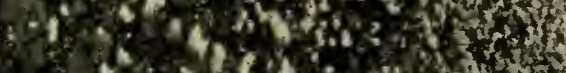

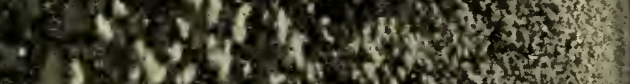
-19 50007 *

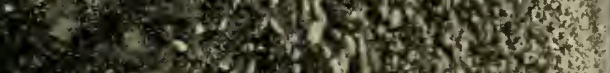
1.

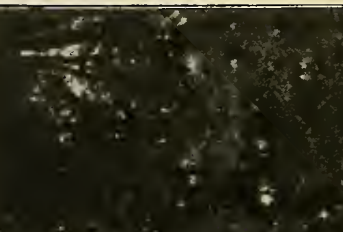

s.

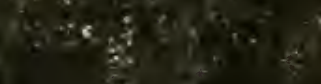

$-5 \cdot 3=402$

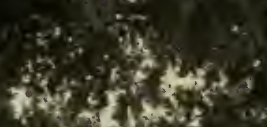

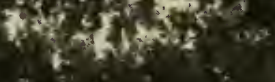

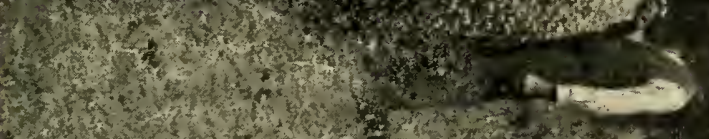

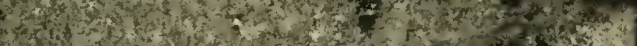

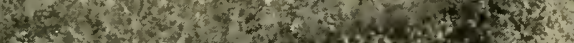

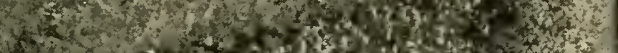

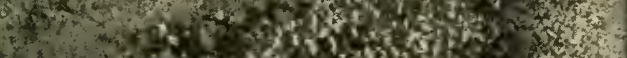

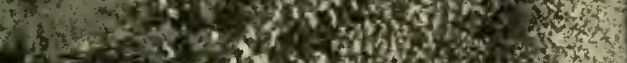
S.t.

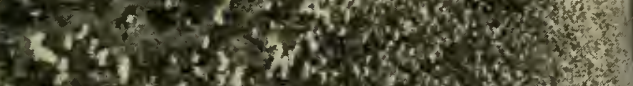

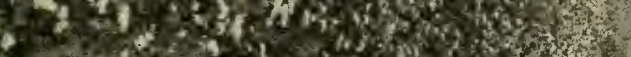

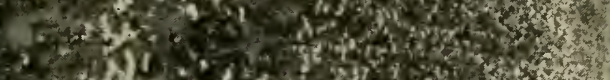

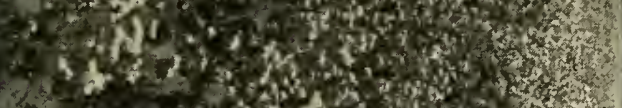

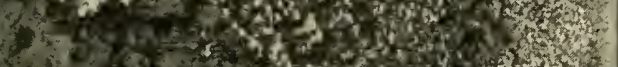

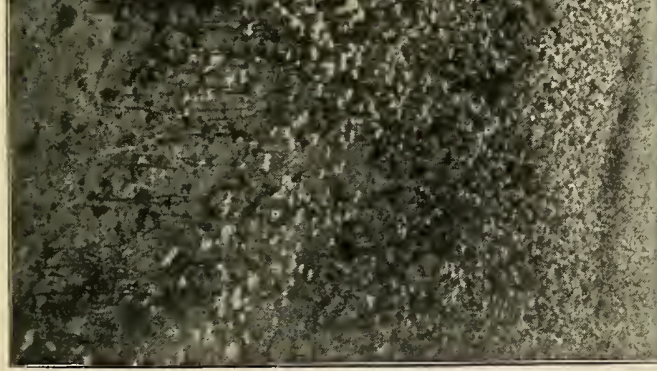

atsen:

\section{y. $x^{2}$}

7. thortson $5 \times 4+5$ in $82 \times ?$ (4)

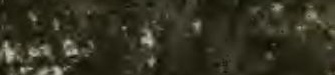
tor at 

The following table shows the details of the fertilizer. tests with buckwheat at the station farm:

Results FOR 1898.

Sowed July 6th, harvested Sept. 13th.

APPLICATION PER ACRE.

YIELD PER ACRE.

Sodium nitrate, 200 tbs.................2. 23.8 bushels Potassium chloride, $200 \mathrm{lbs} \ldots \ldots \ldots \ldots \ldots \ldots \ldots . . \ldots 27.0^{\circ}$ bushels Thomas slag, 200 tbs..................28.6 bushels Acid Phosphate, $200 \mathrm{tbs} . \ldots \ldots \ldots \ldots \ldots \ldots .6 .6$ bushels

RESUlTS FOR 1899.

Sowed July 12th, harvested Sept. 12th.

APPLICATION PER ACRE.

YIELD PER ACRE.

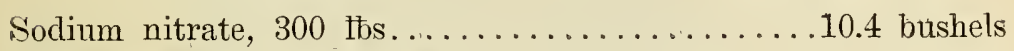
Potassium sulphate, 400 ths............. 9.0 bushels

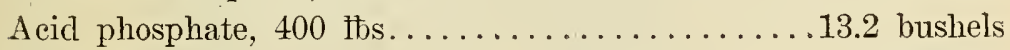
No fertilizer ...................... 9.8 bushels

In 1898 the buckwheat on the plats receiving phosphoric acid grew very luxuriantly, and in all probability the yield would have been at the rate of 40 bushels or more per acre, but is severe wind and rain storm shortly after the buckwheat had begun to bloom, injured the phosphoric acid plats very severely without doing much damage to the other plats with a much shorter growth of straw, so, under normal conditions, the difference in yield would have been much greater than is shown in the table. The photograph, taken three weeks after drilling, shows the striking effect of an abundance of phosphoric acid upon the early development of the buckwheat plant.

In 1899 the dry weather, which began shortly after the buckwheat was sown, and continued almost until the buckwheat was harvested, very materially diminished the yield of all of the plats.

Although the experiments at the station farm do not show 
that phosphoric acid had such a striking influence upon the yieid as was the case in Preston county, yet the beneficial effect is noticeable, and it may be safely concluded that a fertilizer for buckwheat should be very rich in phosphoric acid.

\section{VARIETIES.}

Japanese, Silverhull, Gray and Russian were grown at the Station Farm in 1899, but on account of the very dry weather no conclusion could be drawn from the test of that year, as none of the rarieties yielded a good crop. The following table gives the results obtained at the Station Farm and in Preston county in 1900 and 1901.

Table showing the yield of different varieties of buckwheat. Fertilized at the rate of 300 pounds of acid phosphate per acr

Yield per acre.

\begin{tabular}{|c|c|c|c|c|}
\hline Variety. & Station Farm. & Preston & County. & Arerage \\
\hline & 1900 & 1900 & 1901 & \\
\hline Tapanese & $\begin{array}{l}23.7 \\
26.7\end{array}$ & 39.3 & 35.4 & 31.3 \\
\hline Silverhull & 23.3 & 15.4 & 20.1 & 19.6 \\
\hline Gray & 22.1 & 14.1 & 18.2 & 18.1 \\
\hline Russian ... & 19.5 & 20.6 & 22.5 & 20.9 \\
\hline
\end{tabular}

The Japanese variety gave an average yield of more than ten bushels per acre more than any of the other varieties.

\section{Northern and Southeri Grown Seed.}

In the spring of 1900 some Japanese buckwheat was obtained which had been grown for several years in Ontario, Can!ada. It was sown beside the same variety which had been raiset in West Virginia. The plat seeded to northern grown seed yielded at the rate of 26.7 bushels per acre, and the plat sown to West Virginia seed at the rate of 23.7 bushels, giving a balance in favor of the northern grown seed of exactly three bushels per acre. If future trials show as great an average difference as in this instance, it will pay farmers to obtain seed buckwheat from the North. 


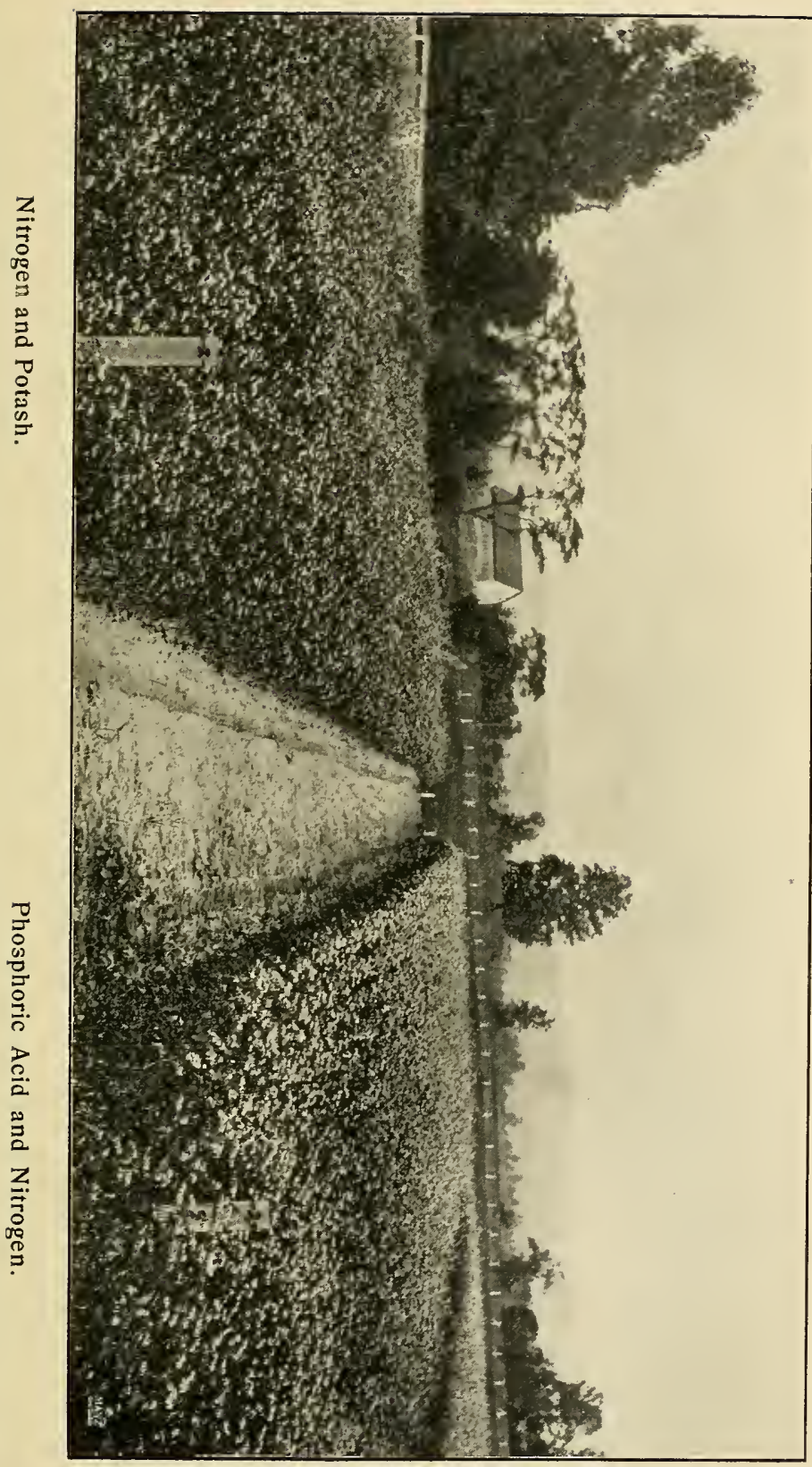





\section{Different Dites of Sowing Buckwheit.}

In a considerable portion of this State two crops of buclswheat can be raised annually, the first crop ripening in July, and the second late in September or early in October. When two crops are raised annually there can be little choice as to the dates of sowing, for then it is necessary to make the first sowing as early as practicable in the spring, and the second as soon as the preceding erop is removed. Buckwheat can be somn without danger from frost quite early, for while the plants are stitl small, with only two leaves, they can endure a fairly sever: frost without injury.

In 1900, two crops of buckwheat were successfully grown upon the Station Farm. For the first crop the seed was sowa May 5th, and the crop was harvested July 26th; for the second crop the seed was sown August 11th, and the crop harvested October 1st. Owing to the severe drought which prevailed during August and September, the second crop was light, but in a year with average rainfall during this period there is no reason why there should not have been a very good second crop.

Several plats were sown to buckwheat at different times in the summer of 1900. The field selected for this test was extremely poor and none of the yields were satisfactory. The fo:lowing table gives the details of the test:

\section{Buckwheat Sown at Different Dates.}

When sown.

$\begin{array}{cc}\text { May } & 5 . \\ 6 & 12 . \\ \text { "6 } & 22 . \\ \text { Jume } & 6 . \\ \text { 66 }\end{array}$

" 21
When harvested.

July 26

" 26

Aug. 10

"، 17

" 20

" 29
Yield per acre.

20.8

20.8

22.5

26.2

25.8

20.0

July 2. Lodged badly by

13. heavy storm and not harvested.

The sowing made May 28th, gave the largest yield. 
Stgaestions Concerning the R.ising of Buchwhelt.

Plow buekwheat land as early as possible in the spring, and harrow oceasionally until the seed is sown. This early plowing and harrowing aids in changing into a soluble and hence available form, some of the insoluble nitrogenous compounds of the soil. This will usually supply suffieient nitrogen. The early plowing also allows the soil to become suffieiently eompaet inmediately below the surface, which is an aid in preventing injury from dry weather. Sow one bushel of seed. and apply from 150 to $300 \mathrm{tbs}$. of aeid phosphate per aere. 


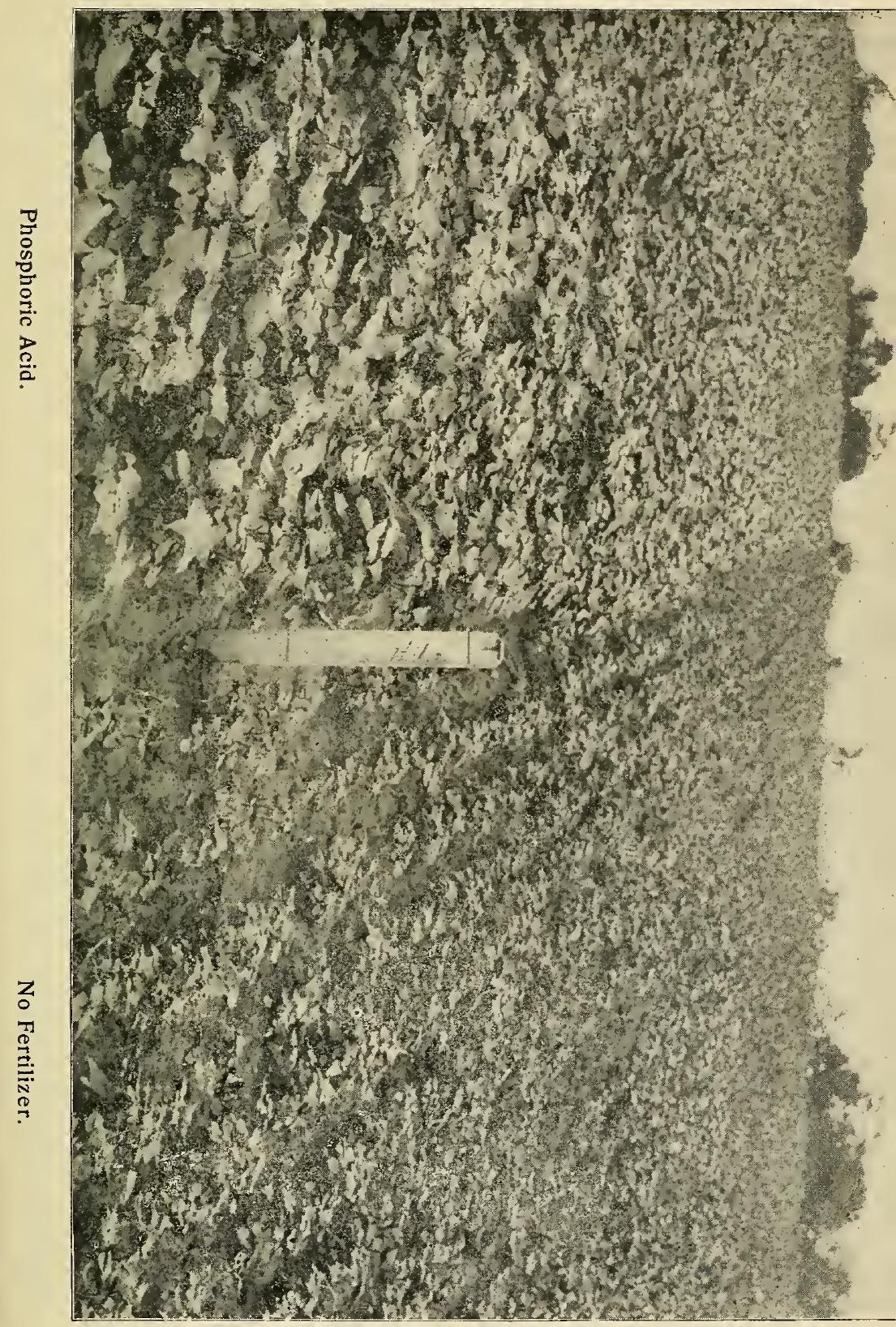





\section{A Variety Test of Oats.}

Oats thrive best in a cool, moist climate, and in those sections of the country where the climatic conditions are not especially favorable for the perfect development of this crop it is of much importance to select those varieties which are best able to withstand the adverse conditions.

During the past three years a number of varieties have been tested and the yields of grain and straw are shown in the following tables :

RESULTS FOR 1900.

The land upon which the oats were grown produced a crop of sugar beets in 1899 . The plowing was done early in the spring, and the oats were drilled on the 10th of April. The plats were each one-twentieth of an acre in size and were uniformly fertilized at the rate of $600 \mathrm{lbs}$. of complete fertilizer per acre. As the latter part of the season was favorable, a farr growth of straw resulted in the case of most of the varieties. All of the varieties were more or less affected with rust and smut, the smut doing the principal damage. The Extra Ripe variety, Black Spring, Black Prolific and Golden Giant were smutted badly.

The following table gives the names of the different varieties, the date of harvest and the yield of grain and straw per acre: 
Viniety.

Seediman. Harvested.

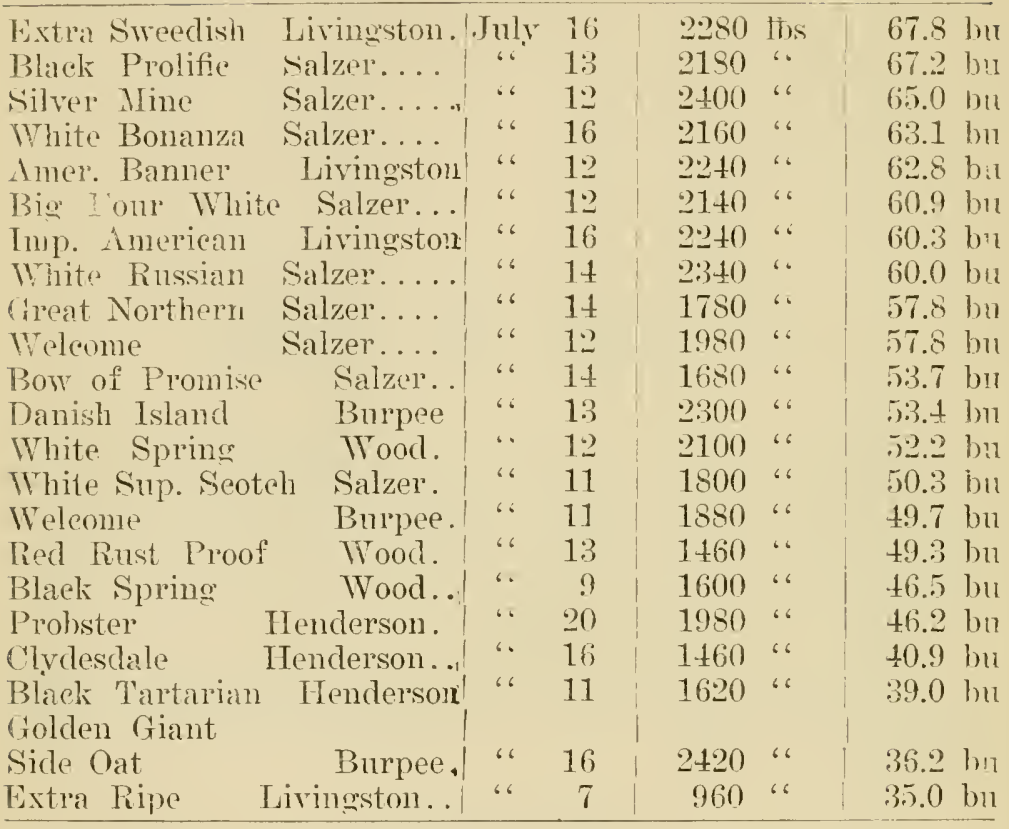

It is seen that eight of the twenty-four varieties produeeri sixty or more bushels per acre. Livingston's Extra Sweedist heads the list with a yield of 67.8 bushels per acre. followed rlosely by Salzer"s Blitek Prolifie.

The different varieties showed considerable rariation in the yield of both grain and straw. Black Prolific produced almost twice as mueh grain and more than twice as much straw as Extra Ripe.

\section{RESULTS FOR 1901.}

'The variety test of oats which was begun last year was continued in 1901 with the addition of a few more varieties.

Before the oats were sown all of the varieties were treaterl for simut by the hot water method which eonsists in soaking the seed for ten minutes in water heated to 132 degrees Fahr. Thic 
treatment was very effective, as there were not a half dozen smutted heads upon the plats where the seeds had been trated, while the oats in an adjoining field, in which mutreated seed was nsed. were smutted badly.

The oats were sown during the first days of Mar, upon a portion of a field which had been in grass for several years. The land was plowed early in January, and when the seed was sown was in good tilth. The seed germinated well and a good stand was obtained with all of the varieties. The growth during the early part of the summer was very rapid and gave promisa of a good rield, but the dry weather following checked growt!n and materially diminished the vield and injured the quality of the grain.

Ther plats were one-trentieth of an acre in size, and were fertilized at the rate of $400 \mathrm{ths}$. of acid phosphate per acre.

The following table gives the yield of grain and straw per acre for each of the different varieties: 
Variety.

Harvested. Straw

Grain

North Finuish Black Oat...Ang.

lig Fom White.........July 2

Nilver Mline........... " " 26

White linssian.......... " " 27

American Banner........ " " 25

lilack Sprine......... " " 23

Janish Island.......... " " 25

Imploved American........ “ 25

Black Tartalian.......... “ “ 25

Great Northern.......... “ " 27

Black Prolifie........... " " 26

Clydesdale ............ " " 26

$2 \quad 2900 \mathrm{lbs}$

$57.5 \mathrm{bn}$

2740 "6

56.3 bil

2820 "

53.1 b:t

$2+20$ "

53.1 bu

2640 -

$52.5 \mathrm{but}$

$50.0 \mathrm{~b} 11$

$49 .+$ b11

49.4 bre

48.1 bu

$\pm 7.5 b 17$

47.5 b11

43.1 bu

White Bonamza........... "

Probster ............. "

Extra Sweedish........... "

White Spring...........

Sixty Day, from Russia,....

Extra Ripe, ............

Golden Giant Sicle Oat.....

White Superior Seoteh. ....

Weleome ..............

Vo. 5032. [. \&. Dept. Agr..| “ 26

Red Rust Proof...........Ang.

Bow of Promise........... July 2

Black IInngarian,from Naples|

26

30

26

26

17

7

30

23

26

26

3140 "

3140 "

3180 "

$3800 \div$

2800 ․

43.1 bil

$35 \% 0$ “

$+2.5 \mathrm{bm}$

4.2 .5 bis

+1.3 bir

40.6 bu

\pm 0.6 bus

$+0.6 \mathrm{bu}$

40.0 bil

37.5 bn

$37.2 \mathrm{~b}$

35.0 bu

33.8 bu

$21.9 \mathrm{bu}$

Among the eight varieties which produced sixty or more bushels of grain per are in 1900. there are five which stanci among the eight leading varieties in 1901. These five varietics are Silver line, Amerienn Banner, Big Four White, Improverl American and White Russian. Extra Sweedish, which led in grain production in 1900, takes the 15th place in 1901. As it stands second in regard to the amomnt of straw produced. it is unite probable that it was injured more by dry weather during the fruiting period than some of the other varieties.

The leading variety in 1901 was North Fimnish Black Oat, a variety not tested last year, closely followed by Big Four White and Silver Mine. 
RESULTS FOR 1902.

This year the oats were sown upon a piece of land which produced a crop of rye in 1901. After the rye was harvestexi the land was plowed and seeded to rye and corrpeas. Both rye and cowpeas made a good growth during the latter part of the summer. The rye was plowed under March 26th, and the oats were drilled April 21st. The plats were one-tenth of an aere in size, and were uniformly fertilized at the rate of 500 pounds of complete ferti!izer per acre. The seed was treated for smut by the hot wat $:$ method with good results.

Owing to lack of room only twelve of the more promising varieties were tested. The table shows the yields of straw and grain per acre:

\section{Tield.}

\begin{tabular}{|c|c|c|c|c|c|}
\hline Variety. & \multicolumn{2}{|c|}{ Harvested. } & \multicolumn{2}{|c|}{ Straw. } & Grain. \\
\hline White Russian. & July 2 & 24 & 23601 & $16 \mathrm{~s}$ & $77.8 \mathrm{bu}$ \\
\hline Improved American..... & 166 & $\cdots$ & 2.250 & “6 & $75.0 \mathrm{but}$ \\
\hline Danish Island. & 66 & 6 & $2 \frac{1}{100}$ & 6 & $75.0 \mathrm{but}$ \\
\hline Anerican Banner.. & '6 & 6 & 2560 & ‘ & $73.1 \mathrm{bu}$ \\
\hline SaIzer's Big Four White... & ، 6 & 19 & 28310 & ‘ & $71.5 \mathrm{bit}$ \\
\hline Extra Sweedish........... & “6 & 24 & 2680 & 6 & $70.9 \mathrm{l}) \mathrm{n}$ \\
\hline Salzer's Silver IIine....... & 66 & . & 2250 & $\cdots$ & $70.3 \mathrm{~b} 11$ \\
\hline White Bonanza........ & 6 & $\therefore$ & 2360 & . & $70.0 \mathrm{buc}$ \\
\hline Black Prolific... & “6 & 66 & 2280 & 6 & $69.3 \mathrm{bu}$ \\
\hline Great Northern. & 66 & 《6 & 2180 & "6 & $69.3 \mathrm{brt}$ \\
\hline North Finnish Black. . & “ & 6 & 2220 & " & $68.1 \mathrm{blt}$ \\
\hline Black Spring......... & 66 & 6 & 1950 & 66 & $62.5 \mathrm{buz}$ \\
\hline
\end{tabular}

The arerage vield, this year, of the twelve varieties, was 71 bushels of weighed oats per acre. Only fonr varieties produced less than 70 bushels per acre, and we may eonclude that nearly all of the varieties named in the preceding table are well adapted to this section.

It is interesting to observe the inflnence of the amomnt of rainfall during the growing period upon the vield of grain. Although the varieties were grown upon a different set of plats each year, and fertilized somewhat differently, yet, as the heav- 
iest application of fertilizer was applied to the poorest land, and vice versa, the arailable plant food at the disposal of the different varieties was practically miform for the three years, and the differences in the arerage yields, for the three years. was largely cansed by differences in the rainfall.

The table shows the amount of rainfall in inches for April, May, Jume and July for the three rears under consideration, and the average rield. for each year, of the trelre rarieties tested in 1902 :

\begin{tabular}{c|ccc|c|c|c} 
Yeal & April & \multicolumn{2}{c}{ Thay } & June & \multicolumn{2}{c}{ July Av. Yield bu } \\
\hline 1900 & 1.51 & 2.14 & 5.39 & 6.93 & 60.4 \\
1901 & 6.15 & 6.10 & 2.34 & 1.86 & 50.1 \\
1902 & 3.48 & 1.71 & 7.16 & 8.42 & 71.0 \\
\hline
\end{tabular}

In 1900 there was a slight deficiency of rainfall in April and May, but suffieient in Jume and .July, and probably if the seed oats that year had been treated for smut the yield would have heen as large as in 1902. In 1901 April and May wer's rery wet months, while Jume and July were rery dry, thus materially reducing the yields. On the other hand, in 1902 th? conditions were reversed, April, and May in particular, being rery dry, and Jume and .July being rery wet and furorable for a large yield of grain. It is thus seen that dry weather in the early part of the growing period does not affect oats so unfavolably as it does when it comes later in the season. 

